\title{
Detoxification enhancement in the gymnodimine-contaminated grooved carpet shell, Ruditapes decussatus (Linné)
}

\author{
Medhioub Walid ${ }^{\mathbf{a}, \mathbf{b},{ }^{*}}$, Guéguen Marielle ${ }^{\mathbf{a}}$, Lassus Patrick ${ }^{\mathbf{a}}$, Bardouil Michèle ${ }^{\mathbf{a}}$, Truquet \\ Philippe $^{a}$, Sibat Manoella ${ }^{a}$, Medhioub Néjib ${ }^{b}$, Soudant Philippe ${ }^{c}$, Kraiem Mejdeddine $^{b}$ and \\ Amzil Zouher ${ }^{\mathrm{a}}$
}

\footnotetext{
a Laboratoire Phycotoxines, IFREMER, Institut Français de Recherche pour l'Exploitation de la Mer (Ifremer), BP 21105, 44311 Nantes Cedex 3, France

${ }^{\mathrm{b}}$ Laboratoire d'Aquaculture, INSTM, Institut National des Sciences et Technologies de la Mer, Route de Kniss 5000 Monastir, Tunisia

c Université de Bretagne Occidentale - IUEM, LEMAR CNRS UMR 6539, Place Nicolas Copernic, technopôle Brest Iroise - 29280 Plouzané, France
}

*: Corresponding author : Medhioub Walid, Tel.: +33 240374272, email address : Walid.Medhioub@ifremer.fr

\begin{abstract}
:
In the Gulf of Gabès (Tunisia, Eastern Mediterranean sea), the grooved carpet shell Ruditapes decussatus has been seen to contain persistent levels of gymnodimine (GYM) for several years. The present experimental work represents the first attempt to assess detoxification kinetics of fast-acting toxins (FAT) in marine molluscs fed specific diets of non-toxic algae (Isochrysis galbana).
\end{abstract}

To find an optimal detoxification method, two experiments were performed in which clams were first fed the toxic dinoflagellate Karenia selliformis to artificially contaminate them with GYM, thus simulating the effect of natural toxic episodes. As a second step, the same clams were fed a non-toxic algae, I. galbana, to speed up the detoxification process.

Changes in toxin content over the whole experiment were assessed by liquid chromatography coupled to tandem mass spectrometry (LC-MS/MS) analysis.

The first results revealed (i) faster detoxification rates in digestive gland (DG) when clams were fed on I. galbana compared with a starved control (no food) and (ii) a typical detoxification pattern, i.e. a rapid drop in toxin content within the first days followed by a secondary slower decrease. GYM levels could be reduced approximately to less than $5 \%$ within 7-8 days in clams fed $I$. galbana, according to the initial toxin levels of 1400 and $9400 \mu \mathrm{g} G Y M / k g$ of DG, respectively. At the end of the second experiment, DSP mouse bioassay was negative when GYM was less than $100 \mu \mathrm{g} / \mathrm{kg}$ DG.

Keywords: Detoxification; Toxicity; Gymnodimine; Karenia selliformis; Grooved carpet shell; Ruditapes decussates 


\section{Introduction}

At least five human syndromes are recognized to be induced by the consumption of phycotoxin-contaminated seafood worldwide. These fall into several groups: paralytic shellfish poisoning (PSP), amnesic shellfish poisoning (ASP), diarrhetic shellfish poisoning (DSP), neurotoxic shellfish poisoning (NSP) and ciguatera fish poisoning (CFP). There is, therefore, a growing consensus among scientists that the presence of toxic phytoplankton in coastal waters is of great significance for human health. The problem also causes serious economic losses due to periodic closure of commercial shellfisheries.

Gymnodimine (GYM) was isolated as a toxic substance from oysters and is unique in containing butenolide, a 16-membered carbocycle and cyclic imine moieties. GYM was chemically characterized by different investigators (Seki et al., 1995; Miles et al., 2000; Miles et al., 2003) (Fig. 1). The biogenetic origin of gymnodimine was identified as the dinoflagellate Karenia selliformis. Two analogs, gymnodimine-B and gymnodimine-C were also isolated from this dinoflagellate (Miles et al., 2000; Miles et al., 2003).

The presence of a spirocyclic imine indicated that this marine toxin belongs to the cyclic imines family, which already includes pinnatoxins (Uemura et al., 1995), pteriatoxins (Takada et al., 2001), prorocentrolides (Chou et al., 1996) and spirolides (Hu et al., 1995).

GYM was later on shown to be widely distributed along New Zealand coastlines, but generally at a low concentration (Stirling, 2001), and was recently identified in digestivegland tissues of clams Ruditapes decussatus from Tunisia (Biré et al., 2002). GYM has also been observed in many other species of contaminated shellfish, including greenshell mussel, blue mussel, scallop, cockle, surfclam, oyster and abalone (Mackenzie et al., 1996; Stirling, 2001; Mackenzie et al., 2002). Furthermore, the toxin is not readily depurated from shellfish, and may persist for years, for example in oysters (Mackenzie et al., 2002). 
More recently, GYM-A has been unequivocally detected in shellfish from European and

North American coasts (Kharrat et al., 2008), and is considered as an emergent 'fast-acting' phycotoxin (FAT). Due to the rapid onset of neurological symptoms in mice and rapid death following intra-peritoneal (i.p.) injection (Mackenzie et al., 1996; Munday et al., 2004). GYM-A has also proved to be toxic to fish (Seki et al., 1995). However, when GYM administered to mice by oral route, toxicity appears to be quite low (Munday et al., 2004). As a result GYM is not considered as a hazard for humans in most concerned countries.

Recent studies tend to demonstrate that GYM-A targets the muscle nicotinic acetylcholine receptor, which could explain its neurotoxicity (Kharrat et al, 2008). When shellfish extracts containing GYM systematically give positive mouse bioassay results for lipophilic compounds, these shellfish cannot be safely consumed. Management of the carpet shell clam fishery requires drastic improvements, particularly the development of routine specific assays to monitor GYM and congeners (McNabb et al., 2005).

In the meantime, the development of detoxification processes could represent a useful option for reducing the final GYM concentration in shellfish meat to a level low enough to produce negative mouse assay results.

The purpose of this study was to determine the impact of non-toxic algal food on detoxification rates, testing the hypothesis that clams fed I. galbana detoxified faster than unfed (control) clams. Thus, the detoxification kinetics of Ruditapes decussatus experimentally contaminated with $K$. selliformis was studied in raceway-based recirculating or flow-through systems.

\section{Materials and methods}

2.1. Experimental contamination of clams fed on Karenia selliformis followed by detoxification with and without nontoxic food. 


\section{Experiment 1}

101

Strain GM95GAB of $K$. selliformis, formerly referred to as Gymnodinium maguelonnense or Karenia sp. (Guillou et al., 2002, Shao et al., 2004), was isolated in 1995 (Arzul et al., 1995) from the Gulf of Gabès (North of Sfax) after an episode of mass fish mortality (Hamza and El-Abed, 1994, Hansen et al., 2004). Unialgal isolates are stored and batch cultured $(250 \mathrm{~mL}$ ) in f/2-medium (Guillard and Ryther 1962, Guillard, 1975) under alternation of light and shade $12 \mathrm{~h} / 12 \mathrm{~h}$ at $52 \pm 4 \mu$ mole photons $/ \mathrm{m}^{2} / \mathrm{s}$ and $16 \pm 0.5^{\circ} \mathrm{C}$. Isochrysis galbana "Tahiti strain" cultures, used as non-toxic live feed for control purposes, were also maintained under the same conditions. For the experiments, K. selliformis and $I$. galbana were grown in larger flasks, i.e. $4 \mathrm{~L}$ and $10 \mathrm{~L}$ flat-bottomed vessels, respectively, with (I. galbana) or without (K. selliformis) air supply. Toxic and non-toxic algal cells were harvested for feeding experiments at the end of the exponential growth phase (12 to 14 days after inoculation, respectively).

Algal-cell concentrations were quantified using a Nageotte hemocytometer.

In March 2007, Ruditapes decussatus clams with no history of phycotoxin contamination were collected from Noirmoutier island in France. Harvested clams were of commercial size, i.e. $37 \pm 2 \mathrm{~mm}$ mean shell length $(\mathrm{n}=10)$ and $0.44 \pm 0.03 \mathrm{~g}$ mean tissue dry weight $(\mathrm{n}=10)$. Samples ( $8 \mathrm{~kg}: 252$ clams) were immediately transported to the IFREMER laboratory (Nantes, France), and acclimatized for 5 to 6 days in a raceway filled with $150 \mathrm{~L}$ seawater, fed on Isochrysis galbana, and maintained at $16 \pm 0.5^{\circ} \mathrm{C}$ (Table 2).

Sea water at a salinity of 35 psu was pumped through the raceways at a flow rate of 800 $\mathrm{L} / \mathrm{h}$ and circulated in a closed system maintained at $16 \pm 0.5^{\circ} \mathrm{C}$. The experimental setting was similar to that previously described in Lassus et al. (1999). Seawater was totally renewed every two days to prevent an increase in ammonia concentration (dissolved ammonia levels were measured every two days using the method of Koroleff (1969). 
During the contamination period, clams were continuously fed on toxic microalgae $K$. selliformis at a concentration of 200 cells/ml for six days; in such a way that available phytoplankton was automatically kept at a steady concentration (autoregulation through Labview ® software / datalogger / fluorescence detection). Clams were sampled for chemical analysis at day 0 and day 6 of contamination. The entire edible tissues and digestive gland of 10 clams were pooled, and their toxicity analysed according to the method described in 2.2.

During a 7-day detoxification, three experimental groups were prepared: in the first, 70 clams were fed I. galbana at 12000 cells $/ \mathrm{ml}$ with the same autoregulation protocol as that described for K. selliformis; in the second group, 70 clams were successively supplied with sea water alone for the three first days of detoxification and then fed I. galbana at the same concentration as group 1; and, in the last group, 70 clams were starved (sea water only) and thus served as a control. During detoxification, clams $(n=10)$ were sampled daily for GYM analysis, i.e. on days $0,1,2,3,4,6$ and 7 . For each daily sample, tests were conducted on pooled digestive gland $(n=10)$ and on pooled remaining flesh fractions $(n=10)$. Chemical analysis were performed three times for each sample $(n=3)$.

No mouse bioassays were performed in this experiment.

\section{Experiment 2}

The same strain of $K$. selliformis was cultured in the INSTM hatchery of Monastir (Tunisia) using 40 L culture tanks of L1 medium (Guillard and Hargraves, 1993) and a 12 h / $12 \mathrm{~h}$ light-dark cycle with a light intensity of $40 \mu$ mole photons $/ \mathrm{m}^{2} / \mathrm{s}$ and temperature regulated at $18 \pm 0.5^{\circ} \mathrm{C}$. Isochrysis galbana "Tahiti strain" cultures were grown in $100 \mathrm{~L}$ polyethylene sheathes in f/2 medium (Guillard and Ryther 1962, Guillard 1975) and maintained under the same conditions.

Both toxic and non-toxic algae were harvested in late-exponential or early-stationary phase after 14-16 days (K. selliformis) and 6-8 days (I. galbana) growth. 
In April 2008, R. decussatus clams with no history of phycotoxin contamination were

151 collected from the Gulf of Gabès in Tunisia. These clams were of commercial size, i.e. $34 \pm$

$1522.3 \mathrm{~mm}$ mean shell length and $0.29 \pm 0.07 \mathrm{~g}$ mean tissue dry weight $(\mathrm{n}=10)$. The clams $(20$

$153 \mathrm{~kg}$ ) were transported under dry and cold conditions to the laboratory where they were

154 acclimatized for 5 to 6 days in a raceway filled with $150 \mathrm{~L}$ seawater at a temperature of $18 \pm$

$155 \quad 0.1^{\circ} \mathrm{C}$ and salinity of $38 \mathrm{psu}$ (Table 2 ).

156 During the contamination period, clams were fed the toxic microalgae $K$. selliformis

157 (harvested in decline-phase after 30 days, $20000 \mathrm{cell} / \mathrm{ml}$ ) for seven days and sampled at days

1580 and 7 of contamination for chemical analysis $(n=10)$ and mouse bioassay $(2 \mathrm{~kg})$ (Table 2).

159 During the detoxification period, two experimental groups were prepared in an open-

160 seawater system: three $150 \mathrm{~L}$ raceways, each containing $5 \mathrm{~kg}$ of clams with a temperature of

$16117 \pm 0.3{ }^{\circ} \mathrm{C}$, salinity of 37 psu and constant seawater flow-rate with total renewal of circulated

162 seawater three times a day.

163 In the first two raceways, clams were fed on I. galbana. The daily algal food ration was

$1642 \%$ DW algae / DW clam meat; clams in the last raceway were starved (sea water only) and 165 thus served as controls.

166 During the detoxification period, clams were sampled, on days $0,1,2,3,4,5,7,8$ and

16710 for GYM quantitative analysis and on days 7, 8 and 10 for mouse bioassay ( $2 \mathrm{~kg})$.

168 For each daily sample, chemical analysis were conducted on pooled digestive gland

$169(\mathrm{n}=10)$. Chemical analysis were performed three times for each sample $(n=3)$.

$170 \quad$ 2.2 Extraction and LC-MS/MS analysis of gymnodimine

$171 \quad$ 2.2.1 Extraction procedure

172

Clam toxin contents were monitored during the detoxification period of both

173 experiments. Clam soft parts were dissected and then divided into two fractions: digestive 
174 gland and remaining tissues (including siphon, foot, gill, adductor muscle and mantle). These

175 two fractions were drained for $2 \mathrm{~h}$ on a Büchner funnel, weighed, and then frozen at $-80^{\circ} \mathrm{C}$.

176 Lipophilic toxins were extracted from $2 \mathrm{~g}$ of homogenized digestive gland or remaining

177 tissue with $15 \mathrm{ml}(3 \times 5 \mathrm{ml})$ of a methanol/water (90/10) solution. After centrifugation $(3000 \mathrm{~g}$,

17815 minutes, $4{ }^{\circ} \mathrm{C}$ ) supernatants were combined and homogenized. A $2 \mathrm{ml}$ sample was ultra-

179 filtered by centrifugation through a $0.2 \mu \mathrm{m}$ membrane (Whatman allipore filter) at $6000 \mathrm{rpm}$

180 for 5 minutes. Five $\mu 1$ of the filtrate were injected into the LC-MS/MS system

181

182

183

184

185

186

187

188

189

190

191

192

193

194

195

196

197

198

\subsubsection{LC-MS/MS analysis}

The LC-MS/MS analysis were performed according to Amzil et al, (2007) using an Agilent 1100 LC model coupled to a triple-quadripole mass spectrometer (API 2000). Toxins were eluted in a $3-\mu \mathrm{m}$ hyperclone MOS C8 column $\left(50 * 2.0 \mathrm{~mm}\right.$, Phenomenex) at $20{ }^{\circ} \mathrm{C}$ with a linear gradient set at $0.2 \mathrm{ml} / \mathrm{min}$.

Analyses were carried out in multiple reaction monitoring (MRM) positive ion mode and the two most intense product ions per compound were selected. The transition conditions chosen for gymnodimine toxins are indicated in table 2.

\subsection{Mouse bioassay}

\subsubsection{Toxin extraction}

The mouse bioassay for the DSP toxins was performed according to the method of Yasumoto et al. (1978). $20 \mathrm{~g}$ digestive glands (DG) from each clam sample were extracted with $50 \mathrm{ml}$ acetone, homogenized with ultra Turax, filtered and then placed in a rotary evaporator. This last step was repeated twice. Finally, after acetone / water evaporation, the dry residue was collected and stirred with glass beads and $4 \mathrm{ml} 1 \%$ Tween 60 before being stored at $-80{ }^{\circ} \mathrm{C}$ until use. 


\subsubsection{Mouse inoculation}

The residue was suspended in $1 \mathrm{ml} 1 \%$ Tween 60 solution and injected intraperitoneally (i.p.) into three mice. Toxicity was determined by time until mouse death following the inoculation with clam extracts. Three control mice were also i.p. injected with 1 $\mathrm{ml}$ Tween standard solution. As soon as inoculation had been made, mice had to be carefully observed, paying special attention to the symptoms occurring within the first $15 \mathrm{~min}$.

The bioassay was considered positive if at least two out of three mice died within $24 \mathrm{~h}$.

\subsection{Filtration rates}

As soon as clam faeces (but not pseudo-faeces) were produced during the feeding period of experiment 1 they were detected and immediately removed with Pasteur pipettes twice a day. The amount of total particulate matter (TPM) and particulate inorganic matter (PIM) in seston (detritic and living particles) are expressed per unit of sampled sea water as:

$$
\mathrm{TPM}_{\text {seston }}\left(\mathrm{mg} \cdot \mathrm{l}^{-1}\right)=\mathrm{PIM}_{\text {seston }}+\mathrm{POM}_{\text {seston }}
$$

Biodeposits of the detoxification period (faeces and pseudo-faeces) amounts were determined by successively heating Whatman filters at $60{ }^{\circ} \mathrm{C}$ for $24 \mathrm{~h}$ and $450{ }^{\circ} \mathrm{C}$ for $1 \mathrm{~h}$. The total particulate matter (TPM) of biodeposits was calculated using the following relationship:

$$
\mathrm{TPM}_{\text {biodeposits }}\left(\mathrm{mg} \cdot \mathrm{h}^{-1} \cdot \text { ind }^{-1}\right)=\left[\left(\mathrm{POM}_{\text {biodeposits }}(\mathrm{mg})+\mathrm{PIM}_{\text {biodeposits }}(\mathrm{mg}) /\right.\right. \text { production time }
$$

\section{(h))/number of clams]}

Filtration rate (FR) was calculated using the following relationship (Hawkins et al., 1996; Urratia et al., 1996):

FR $\left(\mathrm{mg}_{\mathrm{g}} \mathrm{h}^{-1} \cdot \mathrm{g} \mathrm{dmw^{-1 }}\right)=\left[\left(\mathrm{mg}\right.\right.$ inorganic matter issued from faeces and pseudofaeces $\left.\mathrm{h}^{-1}\right) \times[(\mathrm{mg}$ total particulate matter $\mathrm{l}^{-1}$ seawater) / (mg inorganic matter $\mathrm{l}^{-1}$ seawater)]/g of dry meat weight (DMW) of clam. 


\subsection{Condition index}

Condition index $(\mathrm{CI})$ was calculated using the relationship of dry meat weight (DMW) to dry shell weight (DSW) according to the following equation:

$$
\mathrm{CI}=\mathrm{DMW} \times 100 / \mathrm{DSW}
$$

\subsection{Siphon activity}

The opening of siphon ( $R$. decussatus) was monitored every half hour during contamination (clams exposed to K. selliformis) and detoxification periods (clams exposed to Isochrysis galbana or sea water) in experiment 1 .The siphon activity was expressed as the ratio of the number of clams that opened their siphons to the number of clams used in the experiment.

\subsection{Statistical analysis}

Experimental data were analysed using Statgraphics Centurion software. During the three experiments, the impact of food in a raceway was assessed using multifactorial ANOVAs.

Data obtained from chemical analysis (toxicity level on the last days of detoxification compared with the safety threshold) were tested statistically using a $\mathrm{T}$ test.

For P-values less than 0.05 , differences between toxin contents were considered statistically significant at a $95 \%$ confidence level.

\section{Results}

\subsection{Filtration rates during contamination and detoxification periods}

Filtration rates $\left(\mathrm{mg} \cdot \mathrm{h}^{-1} \mathrm{~g} \mathrm{dmw} w^{-1}\right)$ for each treatment during experiment 1 are shown in Fig. 2. The filtration rate (FR) differed significantly during contamination and detoxification periods and for each diet tested during the experiment. The FR of clams fed I. galbana (groups 1 and 2) was higher during detoxification than during contamination. This difference can be correlated with the percentage clearance activity expressed as the percentage of clams 
with siphons open every half hour (Fig. 3). Diets containing the toxic dinoflagellate Karenia 250 selliformis led to apparent reduced clearance activity (20 to $60 \%$ of clams were active), whereas when non-toxic diets were used, an increase was seen in the number of actively and 2) showed a higher FR compared with the starved clams. Overall, the differences in FR during the detoxification period indirectly confirmed that clams were feeding and ingesting food according to expectations of the experimental design.

Biodeposits (total particulate matter : mg. $\mathrm{h}^{-1} \cdot$ ind $^{-1}$ ) for each group of clams during the detoxification period in experiment 1 is shown in Fig. 4. After 7 days detoxification, the amount of biodeposits (TPM) produced differed among treatments. During the first 3 days of detoxification, group 1, which was fed I. galbana, had a higher production than groups 2 and 3. On day 3, the group of clams that had received food showed an increase in TPM. In the treatment without food, only a minor increase in total fecal production was observed during the whole experiment, indicating that no further ingestion occurred (Fig. 4).

\subsection{Distribution of GYM-A in carpet shell tissues during detoxification}

In experiment 1 , on the first day of detoxification, DG contained most of the GYM-A (97\%), whereas other tissues contained only $3 \%$. During the 7 days of detoxification, toxic content in DG decreased rapidly (Fig. 5) to weak level (1.93\%). Conversely, the toxin content of other tissues only decreased slightly during the detoxification period $(1.24 \%)$.

\subsection{Detoxification kinetics in clams fed $K$. selliformis and $I$. galbana successively}

\section{Experiment 1}

Detoxifications kinetics were determined from chemical assessment (LC-MS/MS) of

271 toxin contents in the digestive gland (DG; Fig. 6). Maximal gymnodimine (GYM) levels were

272 obtained at the end of the contamination period: $9491 \pm 2110 \mu \mathrm{g}$ eq GYM/kg DG. This

273 concentration was reduced at day 7 detoxification to $153 \pm 8,320 \pm 22$ and $511 \pm 18 \mu \mathrm{g}$ eq 
274 GYM/kg DG, respectively, for rations 1 (fed), 2 (unfed during the three first days) and 3 275 (starved control). At this time, the lowest concentration of GYM was observed in clams 276 receiving food.

On day 1, the toxin concentration in clams receiving no food (group 2 and 3) was 278 significantly $(\mathrm{P}=0.042)$ higher compared with clams feeding on I. galbana (group 1). On day 2793 , clams receiving food showed a significant decrease in toxicity (1476 \pm 33 to $550 \pm 28 \mu \mathrm{g}$ 280 eq GYM/kg DG at day 4).

After 7 days detoxification, DG of clams that had been fed on nontoxic algae since the first day of detoxification had lost $98 \%$ of their toxin content, whereas clams fed on nontoxic algae since the third day of detoxification had lost $97 \%$ and clams receiving no food (Table 2) only $95 \%$. At the end of detoxification, no differences in clam condition index were observed between the different feeding conditions, except some slightly lower values for unfed clams (day 7: $\mathrm{IC}=5.1 \pm 0.13)$.

In table 2, detoxification rates of Ruditapes decussatus are described by the general negative exponential equation $y_{1}=y_{0} \mathrm{e}^{-\mathrm{kt}}$, which corresponds to a one compartment model (for the group fed on nontoxic algae and for the starved group) where $t=$ detoxification period (day); $y_{0}=$ initial toxin level $\left(\mu \mathrm{g}\right.$ eq $\mathrm{Gym} \mathrm{kg}^{-1}$ of DG) and $k$ represents the detoxification coefficient $\left(\right.$ day $\left.^{-1}\right)$. In this experiment, the ratio between the two detoxification coefficients was 1.37 , with a coefficient of $0.37 \mathrm{~d}^{-1}$ using seawater and $0.51 \mathrm{~d}^{-1}$ with the I. galbana diet

\section{3 (Table 2).}

\section{Experiment 2}

In experiment 2, the maximum GYM level in clam DG $(1238 \pm 159 \mu \mathrm{g}$ eq GYM/kg 296 DG) was observed after 7 days exposure to $K$. selliformis (Fig. 7). At the end of the 
GYM/kg DG) was significantly higher than in clams fed I. galbana $(54 \pm 2.1 \mu \mathrm{g}$ eq GYM/kg

DG) representing $70 \%$ and $96 \%$ drops in toxin content, respectively (Table 2).

The ratio between the two detoxification coefficients in this experiment was 3.04, with a coefficient of $0.092 \mathrm{~d}^{-1}$ in seawater and $0.28 \mathrm{~d}^{-1}$ with the I. galbana diet (Table 2).

It was only on day 8 and 10 that detoxified clams gave a negative result with mouse bioassay (no mouse death). At the end of the detoxification period, differences in condition index between each treatments were observed; values were lower for unfed clams (day 10: IC 305 $=7.5 \pm 1.2 \mathrm{n}=10$ ), in comparison to clams fed on I. galbana (day 10: $\mathrm{IC}=9.2 \pm 1.35 \mathrm{n}=10$ ).

\section{Discussion}

Different feeding processes have been tested to see how they could speed up the 308 elimination of paralytic and diarrheic toxins from bivalve molluscs. Croci et al. (1994) 309 showed that treatment with ozone had no significant effect on diarrheic toxin detoxification. Temperature and salinity seem to have no effect (Blanco et al., 1999), and several authors reported that food supply has little positive effect either (Sampayo et al., 1990; Blanco et al., 1999), while starvation was found to increase the apparent detoxification rate (Svensson, 313 2003).

Field detoxification by moving mussels from toxic to nontoxic environments (relaying) was performed by Haamer et al. (1990), Marcaillou-Le Baut et al. (1993), Poletti et al. (1996) and Blanco et al. (1999). Moreover the availability of nontoxic food has been proposed by

317 several authors to be the main factor affecting diarrheic detoxification in mussels (Haamer et 318 al., 1990; Sampayo et al., 1990; Poletti et al., 1996; Blanco et al., 1999).

Studies on the effects of food on detoxification of contaminants in mussels have been 320 investigated for other types of toxins. Novaczek et al., (1992) and (Wohlgeschaffen et al., 321 (1992) found no difference in detoxification rate of the hydrophilic neurotoxin domoic acid 322 among fed or starved mussels, $M$. edulis. Regarding the effect of environmental factors on 
paralytic shellfish toxin (PST) detoxification rates in Mytilus galloprovincialis, Blanco et al., (1997) found that phytoplankton concentration seemed to have no particular effects. Chen and Chou, (2001) observed that detoxification efficiency of (PST) in the purple clam, Hiatula rostrata was similar for clams fed nontoxic algae or starved.

No attempt had been made to detoxify GYM contaminated shellfish before the present study. In this work, our method consisted of transferring clams to waters free of toxic organisms, with environmental conditions that could promote accelerated detoxification. The experiments aimed to test the effects of food on detoxification under controlled conditions. It was found that clams fed non toxic algae had the highest amount of fecal production compared with starved animals. This confirmed that ingestion rates differed among treatments according to predictions, and in this way the experiment was successful.

Moreover, during the contamination period the clams showed a significant reduction in

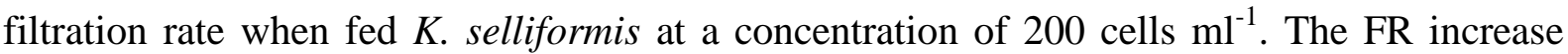
when exposed to I. galbana at a concentration of 12000 cell ml$^{-1}$ at the beginning of detoxification period. This suggest that $K$. selliformis diet is inappropriate and probably harmful for grooved carpet.

GYM detoxification kinetics were faster in clams fed on I. galbana (experiments 1 and 2) than in starved clams. These results are in agreement with other studies such as detoxification experiments with blue mussels, which showed that feeding mussels accelerated

342 the detoxification process. Moreover, observations made by Sampayo et al. (1990) during

343 several DSP episodes on the Portuguese coast, suggested that the detoxification rate increases 344 with phytoplankton concentration, i.e with the main food for bivalve molluscs. These findings 345 contrast with the experiments carried out by Svensson, (2003), who showed that 346 detoxification of lipophilic phycotoxin (okadaic acid) in mussels was unaffected by food 347 availability. 
During the two experiments, detoxification rates were rapid (7 to 8 days) whatever non-

toxic algal diets were used. Thus, in order to set up a process that will optimize detoxification, the presence of I. galbana is a very significant element to help reach the estimated safety threshold. These observations seem consistent with Bricelj and Shumway's (1998) classification of $R$. decussatus as a "fast detoxifier" with in the same time frame as Crassostrea gigas for paralytic toxins

In this study, the initial toxicity was much higher in experiment $1(9491 \pm 2110 \mu \mathrm{g}$ eq GYM/kg DG) than in experiment $2(1238 \pm 159 \mu \mathrm{g}$ eq GYM/kg DG). This difference can be attributed to the high number of clams and the low toxicity of Karenia selliformis used in experiment 2 (2.6 pg GYM/cell compared with $10.7 \mathrm{pg}$ GYM/cell in experiment 1). Clam 358 digestive gland accumulated most of the total GYM (97\%), and the remaining toxins were 359 distributed in the other tissues. This disproportionate accumulation agrees with results 360 obtained for other bivalve molluscs, like scallops (Cembella et al., 1993; Choi et al., 2003), 361 mussels (Bricelj et al., 1990) and Hiatula rostrata (Chen and Chou, 2001). Most studies have 362 concluded that bivalve viscera and DG accumulated most of the total toxin burden, despite the 363 limited contribution of these organs to the total body burden (Bricelj et al., 1990; Cembella et 364 al., 1993).

The different detoxification rates for each kind of tissue may cause an increase in the 366 percentage contribution of the digestive gland to the whole shellfish toxin burden as 367 detoxification progresses, e.g. in the case of Argopecten irradians the percentage increased to $36895 \%$ after two days of detoxification. In our study, it was observed that DG detoxification 369 rate in clams (fed and unfed) was faster during the first two days (more than $84 \%$ loss) but 370 then subsequently slowed down. This suggests that toxins are distributed between these two 371 compartments. Similar patterns were also observed for blue mussels (Marcaillou-Le Baut et 372 al., 1993; Fernandez et al., 1998; Blanco et al., 1999) and also for scallops (Bauder et al., 
1996). This last author found that the rapid loss of toxins during the first 3 days of detoxification coincided with the evacuation of toxin-producing algae from the viscera. Biphasic (fast and slow) detoxification kinetics were also found for other types of algal toxins in different shellfish species, like PSP in king scallop Pecten maximus (Lassus et al., 1989), or DSP in blue mussels (Marcaillou-Lebaut et al., 1993).

The slow detoxification rates shown in other tissues (including gill, mantle, siphon and foot) were in agreement with previous studies such those as in surfclams, S. solidissima. According to Bricelj and Cembella, (1995) the rank order of various tissue pools in terms of their detoxification rates is as follows: viscera $>$ gill $>$ mantle $>$ siphon $>$ foot $>$ adductor muscle. The two experiments we carried out reveal that the detoxification of clams fed with $I$. galbana could be achieved in 7 or 8 days (experiments 1 and 2, respectively). As described in the "material and methods" section, mouse bioassay was done only in experiment 2. This experiment revealed that toxicities in the fed clams were $134 \pm 11.34,55 \pm 5.6$ and $54 \pm 2.1$ $\mu \mathrm{g} \mathrm{GYM} / \mathrm{kg}$ DG after 7, 8 and 10 days of detoxification, respectively, and negative mouse test results were only found after 8 and 10 days. In contrast, clams that were not fed during the detoxification period, which had final toxicities of $366 \pm 66.46,363 \pm 20.43$ and $375 \pm$ $25.89 \mu \mathrm{g}$ of $\mathrm{GYM} / \mathrm{kg}$ DG after 7,8 and 10 days of detoxification, respectively, showed a positive result in the mouse test.

The correspondence of these chemical analyses with the results of the mouse biotest showed that toxicity over $55 \mu \mathrm{g} \mathrm{GYM} / \mathrm{kg}$ DG was responsible for the death of all three mice. Indeed, the presence of GYMs in mice appears through body stretching, hyperactivity, stiff tail, slowing of movements and paralysis of the rear limbs followed by rapid mortality. These symptoms are all neurological (Hu et al, 1996; Cembella et al, 2000; Takada et al., 2001). Moreover, GYM is listed among toxins with a fast action FAT (fast-acting toxins) since it results in the death of mice within a span of a few minutes (Rein and Borrone, 1999). Another 
significant toxicological characteristic of fast acting toxins lies in the differential expression

399 of toxicity according to the toxin levels present in the extracts of tested mice. Indeed, these toxins present an "all or nothing" effect, (Hu and al., 1996; MacKenzie et al., 1996 ; Hu et al., 2001), initially observed by Tindall et al., (1984). This effect is characterized by a sharp disappearance of the mouse lethality once the injected extracts are diluted beyond a certain 403 threshold (MacKenzie et al., 1996).

404

405

406

407

408

409

\section{Conclusions}

Controlled detoxification applied to GYM-contaminated shellfish could be a practical approach for the management of clam fisheries, particularly to ensure a continuous supply of safe clams for the market. The results obtained in this study have shown that detoxification occurs when a non-toxic alga is present in the detoxification system and that GYM levels can be reduced to approximately $5 \%$ of initial toxin content within 7 to 8 days for laboratorycontaminated clams i.e. it is possible to obtain toxin levels below the safety threshold of 100 $\mu \mathrm{g}$ GYM/kg DG. To optimise the conditions for GYM detoxification in clams, feeding with nontoxic algae can be started some days after the beginning of the detoxification process (after 3 days of starvation, for instance). However, more information is needed about seasonal variability and the effect of salinity, specific toxicity of algal strains, bloom duration and cell concentration on the detoxification rates. Further experiments are also needed on naturally contaminated clams. Taking into consideration these different aspects should considerably reduce concerns about health risks related to the consumption of gymnodimine-contaminated R. decussatus.

\section{Acknowledgements}

This work was supported by the convention framework between the Tunisian National Institute of Marine Science and Technologies (INSTM) and the French Research Institute for Exploitation of the Sea (IFREMER). 


\section{References}

424 Amzil, Z., Sibat, M., Royer, F., Masson, N., Abadie, E., 2007. Report on the first detection of 425 Pectenotoxin-2, Spirolide-A and their derivatives in French shellfish. Mar. Drugs. 5, 168-179. 426 Arzul, G., Turki, S., Hamza, A., Daniel, P., Merceron, M., 1995. Fish kills induced by 427 phycotoxins. Toxicon, 33, p. 1119.

428 Bauder, A. G., Cembella, A.D., Quilliam, M.A., 1996. Dynamics of Diarrhetic Shellfish 429 Toxins from the dinoflagellate Prorocentrum lima, in the bay scallop, Argopecten irradians. 430 In: Yasumoto, T., Oshima, Y. Eds, Harmful and Toxic Algal Blooms, Elseiver, Amsterdam, 431 pp. 433-436.

432 Biré, R., Krys, S., Frémy, J.M., Dragacci, S., Stirling, D., Kharrat, R., 2002. First evidence on 433 occurrence of gymnodimine in clams from Tunisia. J. Nat.Toxins, 11, 269-275.

434 Blanco, J., Morono, A., Franco, J., Reyero, M.I., 1997. PSP detoxification kinetics in the 435 mussel Mytilus galloprovincialis. one and two-compartement models and the effect of some 436 environmental variables. Mar. Ecol., Prog. Ser. 176, 165-175.

437 Blanco, J., Fernandez, M.J., Miguez, A., Morono, A., 1999. Okadaic acid depuration in the 438 mussel Mytilus galloprovincialis: one and two-compartement models and the effect of 439 environmental conditions. Mar. Ecol., Prog. Ser. 176, 153-359.

440 Bricelj, V.M., Lee, J.H., Cembella, A.D., Anderson, D.M., 1990. Uptake kinetics of paralytic 441 shellfish toxins from the dinoflagellate Alexandrium fundyense in the mussel Mytilus edulis. 442 Mar. Ecol. Progr. Ser., 63, 177-188.

443 Bricelj, V.M., Lee, J.H, Cembella, A.D., 1991. Influence of dinoflagellate cell toxicity on 444 uptake and loss of paralytic shellfish toxins in the northern quahog Mercenaria mercenaria. 445 Mar Ecol Prog Ser 74, 33-46. 
Bricelj, V.M., Cembella, AD., 1995. Fate of gonyautoxins in surf-clams, spisula solidissima, grazing upon toxigenic Alexandrium. In: Lassus P, Arzul G, Erard E, Gentien P, Marcaillou C eds Harmful marine algal blooms. Lavoisier, Intercept Ltd, Paris, 413-418.

Bricelj, V.M., Shumway S.E., 1998. Paralytic shellfish toxins in bivalve mollusks:

Chen, C. Y., Chou, H.N., 2001. Accumulation and depuration of paralytic shellfish poisoning toxins by urple clam Hiatula rostrata Lighttoot. Toxicon 39, 1029-1034.

453 Choi, K.S., Wilson, E.A., Lewis, D.H., Powell, E.N., Ray, S.M 1989. The energetic costs of 454 Perkinsus marinus in oysters: quantification of the thioglycollate method. J. Shellfish Res. 8, $125-131$.

Choi, M.C., Hsieh, D.P.H., Lam, P.K.S., Wang, W.X., 2003. Field depuration and 457 biotransformation of paralytic shellfish toxins in scallop Chlamys nobilis and green-lipped mussel Perna viridis. Mar. Bio.143, 927-934.

Chou, T.T., de Freitas, A. S. W., Curtis. J. L. C. 1996. Isolation and structure of 460 prorocentrolide B a fast-acting toxin from Prorocentrum maculosum. J. Nat. Prod. 59, 10104611014.

462 Croci, L., Toti, L., De Medici, D., Cozzi, L., 1994. Diarrhetic shellfish poisoning in mussels: 463 comparison of methods of detection and determination of the effectivness of depuration . Int. J. Food Microbiol. 24, 337-342.

465 Cembella, A.D., Shumway, S.E., Lewis, N.I., 1993. Anatomical distribution and spatio466 temporal variation in paralytic shellfish toxin composition in two bivalve species from the 467 Gulf of Maine. J Shellfish Res 12(2): 389-403.

468 Cembella, A. D., Lewis, N. I. \& Quilliam, M., 2000. The marine dinoflagellate Alexandrium 469 ostenfeldii (Dinophyceae) as the causative organism of spirolide shellfish toxins. Phycologia $39,67-74$. 
471 Fernandez, M.L., Miguez, A., Morono, A., Cacho, E., Martinez, A., Blanco, J., 1998.

472 Depuration of low polarity toxins DTX-3 from mussels Mytilus galloproviencialis in Spain;

473 In: Reguera, B., Blanco, J., Fernandez, M.L., Wyatt, T. Eds, Harmful Algae. Xunta de Galicia

474 and Intergovernmental Oceanographic Commision of UNESCO, pp. 449-452.

475 Guillard, R.R.L. and Hargraves, P.E., 1993. Strichochrysis immobilis is diatom, not a 476 chrysophyte. Phycologia 32: 234-236

477 Guillard, R.R.L. 1975. Culture of phytoplankton for feeding marine invertebrates.. In Smith, 478 W.L. and Chanley. M.H. Culture of Marine Invertebrate Animals. Plenum Press, New York, 479 USA, pp. 26-60.

480 Guillard, R.R.L and Ryther J.H., 1962. Studies of marine planktonic diatoms. I. Cyclotella 481 nana Hustedt and Detonula confervacea Cleve. Can. J. Microbiol. 8: 229-239.

482 Guillou, L., Nézan, E., Cueff, V., Erard-Le Denn, E., Cambon-Bonavitta, M., Gentiens, P., 483 Barbier, G., 2002. Genetic diversity and molecular detection of three toxic dinoflagellate 484 genera (Alexandrium, Dinophisis, and Karenia) from French Coasts. Protist 153, 223-238.

485 Haamer, J., Andersson, P.O., Lange, S., Li,X,P., Edebo, L., 1990. Effects of transplantation 486 and reimmersion of mussels Mytilus edulis L. on their contents of okadaic acid. J. Shellfish 487 Res. $9(1), 109-112$.

488 Hamza, A., et EL-Abed, A., 1994. Les eaux colorées dans le golfe de Gabès : Bilan de six ans 489 de surveillance (1989-1994). Bull. Inst. Nat. Scient. Tech. Mer, 21, 66-72.

490 Hansen, G., Erard-Le Denn, E., Daugbjerg, N., Rodriguez, F., 2004. Karenia selliformis 491 responsible for the fish-kills in the Gulf of Gabes, Tunisia 1994. Communication Ifremer: 492 Poster présenté à la Conférence Internationale sur le phytoplancton toxique.

493 Hawkins A.J.S., Smith R.F.M., Bayne B.L., Héral M., 1996. Novel observations underlying 494 fast growth of suspension-feeding shellfish in turbid environments: Mytilus edulis. 495 Mar.Ecol.Progrs.Ser. 131,179-190. 
Hu, T., Curtis, J.M., Oshima, Y., Quilliam, M., Walter, J.A., Wastson-Wright, W.M., Wright,

497 J. L., 1995. Spirolides B and D, two novel macrocycles isolated from the digestive glands of 498 shellfish. J. Chem. Soc. Chem. Comm. 2159-2161.

499 Hu, T., deFreitas, A. S., Curtis, J. M., Oshima, Y., Walter, J. A., Wright, J. L., 1996. Isolation 500 and structure of prorocentrolide B, a fast-acting toxin from Prorocentrum maculosum. J Nat 501 Prod 59, 1010-1014.

502 Hu, T., Burton, I. W., Cembella, A. D., Curtis, J. M., Quilliam, M. A., Walter, J. A., Wright, 503 J. L., 2001. Characterization of spirolides A, C, and 13-desmethyl C, new marine toxins 504 isolated from toxic plankton and contaminated shellfish. J. Nat. Prod 64, 308-312.

505 Kharrat, R., Servent, D., Girard, E., Ouanounou, G., Amar, M., Marrouchi, R., Benoit, E., 506 Molgo, J., 2008. The marine phycotoxin gymnodimine targets muscular and neuronal 507 nicotinic acetylcholine receptor subtypes with high affinity. J. neurochem 107, 952-963.

508 Koroleff, F., 1969. Direct determination of ammonia in natural waters as indophenol blue.

509 ICES, CM, C, 9 Hydro. Comm.

510 Lassus, P., Fremy, J.M., Ledoux, M., Bardouil, M., Bochec, M., 1989. Patterns of 511 experimental contamination by Protogonyaulax tamarensis in some French commercial 512 shellfish. Toxicon 12: 1313-1321.

513 Lassus, P., 1999. Effect of a continuous supply of the toxic dinoflagellate Alexandrium 514 minutum halim on the feeding behavior of the pacific oyster (Crassostrea gigas Thunberg).J. 515 Schell. Rea. 18 (1): 211-216.

516 Marcaillou-Le Baut, C., Bardin, B., Bardouil, M., Bohec, M., Le Dean, L., Masselin, P., 517 Truquet, P., 1993. DSP depuration rates mussels reared in a laboratory and an aquaculture 518 pond. In: Smayda TJ, Shimizu Y (eds), toxic phytoplankton blooms at the sea. Elsevier, 519 Amsterdam, p 531-535. 
MacKenzie, A. L., Haywood, A., Adamson, J., Truman, P., Till, D., Seki, T., Satake, M.,

521 Yasumoto, T., 1996. Gymnodimine contamination of shellfish in New 35 Zealand. In:

522 Yasumoto, T., Oshima, Y., Fukuyo, Y., (Eds) Harmful and Toxic Algal Bloom, IOC-

UNESCO Publish., pp 97-100.

524 MacKenzie, L., Beuzenberg, V., McNabb, P., 2002. Production of gymnodimine by Karenia 525 selliformis (Haywood et al.) In: Steidinger, K. A., Landsberg, J.H., Tomas, C.R., Vargo, G.A. 526 (Eds), Florida Fish and Wildlife Conservation. Commission and Intergovernmental Oceanographic Commission of UNESCO, pp. 160-162.

McNabb, P., Selwood, A.1., Holland, P.T. 2005. Multiresidue method for determination of 88 (3), pp. 761-772.

531 Miles, C.O., Wilkins, A.L., Stirling, D.J., MacKenzie, A.L., Munday, R., Prinsep, M. R., 532 Hawkes, A. D. \& Towers, N., 2000. Chemistry and toxicity of gymnodimine and analogues. In Ninth International Conference on Harmful Algal Blooms. Hobart, Tasmania.

534 Miles, C.O., Wilkins, A.L., Stirling, D.J., MacKenzie, A.L. 2003. Gymnodimine C, an 535 isomer of gymnodimine B, from Karenia selliformis. J. Agric. Food Chem. 51, 4838- 4840.

536 Munday, R., Towers, N.R., MacKenzie, L., Rhodes, L., Beuzenberg, V., Holland, P.T., Miles, 537 C.O., 2004. Acute toxicity of gymnodimine in mice. Toxicon 44, 173-178.

538 Novaczek, I., Madhyastha, M.S., Ablett, R.F., Donald, A., Johnson, G., Nijjar, M.S., Sims, 539 D.E., 1992. Depuration of domoic acid from live blue mussels (Mytilus edulis). Can. J. Fish $540 \quad$ Aquat. Sci. 49,312-318.

541 Poletti, R., Viviani, R., Cassadei, C., Lucentini, L., Funari, E., draisci, R., 1996. depuration 542 dynamics of mussels naturally contaminated with diarrhetic toxins relocated to a basin of the 543 Adriatic sea In : Yasumuto, T., Oshima, Y., Fukuyo, Y Eds Harmful and Toxic Algal Blooms. 544 Intergovenmental Oceanographic Commision of UNESCO, pp. 429-432. 
545 Rein, K. S., and Borrone, J., 1999. Polyketides from dinoflagellates : origin, pharmacology

546 and biosynthesis. Comparative Biochemistry and Physiology Part B 124, 117-131.

547 Sampayo, M.A., Alvito, P., Franca, S., Sousa, I., 1990. Dinophysis spp, toxicity and relation

548 to accompanying species. In: Granéli, E., Sundstrom, B., Edler, L., Anderson, D.M.M Eds,

549 Toxic Marine Phytoplankton. Elseiver, New York, pp. 215-220.

550 Seki, T., Satake, M., Mackenzie, L., Kaspar, H.F., \& Yasumoto, T., 1995. Gymnodimine, a 551 new marine toxin of unprecedent structure isolated from New Zealand oysters and the 552 dinoflagellate, Gymnodinium sp. Tetrahedron Letters 36, 7093-7096.

553 Shao, P., Chen, Y-Q., Zhou, H., Yuan, J., Qu, L-H., Zhao, D., Lin, Y-S., 2004. Genetic 554 varibility in Gymnodiniaceae ITS regions: implication for species identification and 555 phylogenetic analyses. Mar. Biol. 144, 215-224.

556 Stirling, D. J., 2001. Survey of historical New Zealand shellfish samples for accumulation of 557 gymnodimine. New Zealand Journal of Marine and freshwater Research 35, 851-857.

558 Svensson, S., 2003. Depuration of Okadaic acid (Diarrhetic Shellfish Toxin) in mussels, 559 Mytilus edulis (Linnaeus), feeding on different quantities of nontoxic algae. Aquaculture 218, $560 \quad 277-291$.

561 Takada, N., Umemura, N., Suenaga, K., Uemura, D., 2001. Structural determination of 562 pteriatoxins A, B and C, extremly potent toxins from the bivalve Pteria penguin. Tetrahedron 563 Letters 42, 3495-3497.

564 Tindall, D. R., Dickey, R. W., Carlson, R. D. \& Morey-Gaines, G., 1984. Ciguatoxic 565 dinoflagellates from the Caribbean sea. In Seafood toxins. Edited by E. P. Ragelis. ACS 566 Symposium Series 262. Washington, D.C.: American Chemical Society. pp. 225-240.

567 Uemura, D., Chou, T., Haino, T., Nagatsu, A., Fukuzawa, S., Zheng, S., Chen, H., 1995. 568 Pinnatoxin A, a toxic amphoteric macrocycle from Okinawan bivalve Pinna muricata. J. Am. 569 Chem. Soc. 117, 1155-1156. 
570 Urratia, M.B., Iglesias J.I.P., Navarro E., Prou J., 1996. Feeding and absorption in

571 Cerastoderma edule under environmental conditions in the Bay of Marennes-Oleron (western 572 France). J. Mar. Biol., Asso., UK, 76(2), 431-450.

573 Yasumoto T., Oshima Y., Yamaguchi M., 1978. Occurence of a new type of shellfish 574 poisoning in the Tohoku district. Bull; Jpn. Soc. Sci. Fish., 44(11), 1249-1255.

575 Wohlgeschaffen, G.D., Mann, K.H., Subba Rao, D.V., Pocklington, R., 1992. Dynamics of 576 the phycotoxin domoic acid: accumulation and excretion in two commercially important 577 bivalves. J. Appl. Phycol. 4, 297-310.

578

579

580

581

582 
1 Table 1. m/z transition conditions for GYM-A and GYM-B. m/z (mass to charge ratio).

\begin{tabular}{|l|c|}
\hline Toxins & Transitions $\mathbf{~ m} / \mathbf{z}$ \\
\hline GYM A & $508.4>490.2 / 392.3$ \\
\hline GYM B & $524.4>506.4$ \\
\hline
\end{tabular}

2 
Table 2. Summary of experimental conditions, exponential equation, comparison of bioassays and chemical analysis after detoxification period.

\begin{tabular}{|c|c|c|c|c|c|c|c|c|c|}
\hline Clam group & $\begin{array}{c}\text { Origin/Date/shell } \\
\text { length }\end{array}$ & $\begin{array}{l}\text { Acclimation } \\
\text { period } \\
\text { (days) }\end{array}$ & $\begin{array}{l}\text { Contamination } \\
\text { period (days) }\end{array}$ & & $\begin{array}{l}\text { ification } \\
\text { d (days) / } \\
\text { perature }\end{array}$ & $\begin{array}{r}\text { Initial tox } \\
\qquad(\mu\end{array}$ & inal toxin & $\begin{array}{c}\text { DSP Mouse } \\
\text { bioassay }\end{array}$ & Exponential equation \\
\hline \multicolumn{10}{|l|}{ Experiment 1} \\
\hline \multirow[t]{2}{*}{ Control } & & \multirow{4}{*}{$5-6$} & \multirow{4}{*}{6} & \multirow{4}{*}{7} & \multirow{4}{*}{$16 \pm 0.5^{\circ} \mathrm{C}$} & \multirow[b]{3}{*}{9491} & \multirow[t]{2}{*}{511} & \multirow{4}{*}{ Not done } & $\begin{array}{c}\mathrm{y}=4751 \exp (-0.3722 \mathrm{t}) \\
\mathrm{R}^{2}=0.8581\end{array}$ \\
\hline & Island Noirmoutier & & & & & & & & \\
\hline $\begin{array}{l}\text { With algal } \\
\text { food* }\end{array}$ & $\begin{array}{c}\text { (France) } \\
\text { March } 2007 \\
37 \pm 2 \mathrm{~mm}\end{array}$ & & & & & & 320 & & $\begin{array}{c}y=6412.8 \exp (0.5113 t) \\
R^{2}=0.9083\end{array}$ \\
\hline $\begin{array}{l}\text { With algal } \\
\text { food }\end{array}$ & & & & & & \multicolumn{2}{|r|}{153} & & $\begin{array}{c}\mathrm{y}=2970 \exp (-0.5044 \mathrm{t}) \\
\mathrm{R}^{2}=0.791\end{array}$ \\
\hline \multicolumn{10}{|l|}{ Experiment 2} \\
\hline Control & $\begin{array}{l}\text { Golf of Gabès } \\
\text { (Tunisia) }\end{array}$ & \multirow{2}{*}{$5-6$} & \multirow{2}{*}{7} & \multirow{2}{*}{8} & \multirow{2}{*}{$17 \pm 0.3^{\circ} \mathrm{C}$} & \multirow{2}{*}{1238} & 363 & + & $\begin{array}{c}y=733.25 \exp (-0.0922 t) \\
R^{2}=0.5963\end{array}$ \\
\hline $\begin{array}{l}\text { With algal } \\
\text { food }\end{array}$ & $\begin{array}{l}\text { April } 2008 \\
34 \pm 2.3 \mathrm{~mm}\end{array}$ & & & & & & 55 & - & $\begin{array}{c}y=716.57 \exp (-0.2803 t) \\
R^{2}=0.912\end{array}$ \\
\hline
\end{tabular}

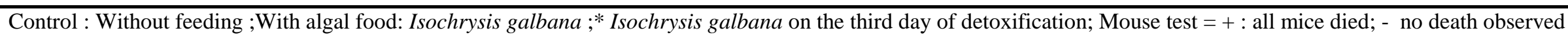




\section{Figures}

Fig.1. Gymnodimine structure.

Fig.2. Filtration rates $\left(\mathrm{mg} / \mathrm{h}^{-1} \mathrm{~g} \mathrm{dmw}{ }^{-1}\right)$ of clams exposed to (A) Karenia selliformis (contamination period) and (B) Isochrysis galbana or sea water during experiment 1 (detoxification period). Triangles $(\Delta)$ : starved clams, squares $(\mathbf{\square})$ : clams fed from the third day of detoxification, and circles $(\bullet)$ : clams fed throughout detoxification.

Fig.3. Percentage of clams with opened siphon (siphon activity) exposed to (A) Karenia selliformis (contamination period) and (B) Isochrysis galbana or sea water during experiment 1 (detoxification period). Triangles $(\Delta)$ : starved clams, squares $(\mathbf{\square})$ : clams fed from the third day of detoxification, and circles $(\bullet)$ : clams fed throughout detoxification.

Fig.4. Biodeposits (total particulate matter production : $\mathrm{mg} \cdot \mathrm{h}^{-1} \cdot \mathrm{ind}^{-1}$ ) of clams exposed to Isochrysis galbana or sea water during detoxification period of experiment 1 . Triangles $(\Delta)$ : starved clams, squares ( $\mathbf{\square})$ :clams fed from the third day of detoxification, and circles $(\bullet)$ : clams fed throughout detoxification.

Fig.5. Relative toxicity (\%) between DG and other tissues during detoxification period according to clams receiving food during the experiment 1.

Fig.6. Clam detoxification kinetics according to the different detoxification diets used in experiment 1. Triangles $(\Delta)$ : starved clams, squares $(\boldsymbol{\square})$ : clams fed from the third day of detoxification, and circles $(\bullet)$ : clams fed throughout detoxification. Mean values \pm S.E. (3 chemical analysis for any point and diet used).

Fig. 7. Clam detoxification kinetics according to the different diets used in experiment 2. Triangles $(\Delta)$ : starved clams, squares $(\mathbf{\square})$ : fed clams. Mean values \pm S.E. (3 chemical analysis for any point and diet used). 
Fig. 1

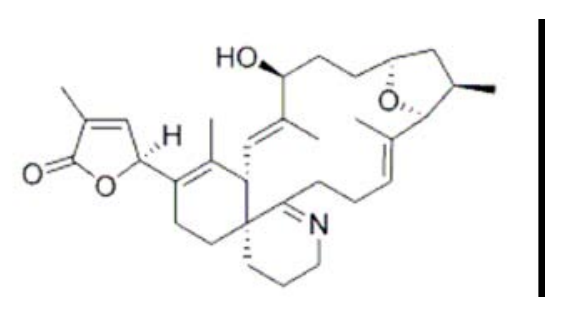

Fig.2

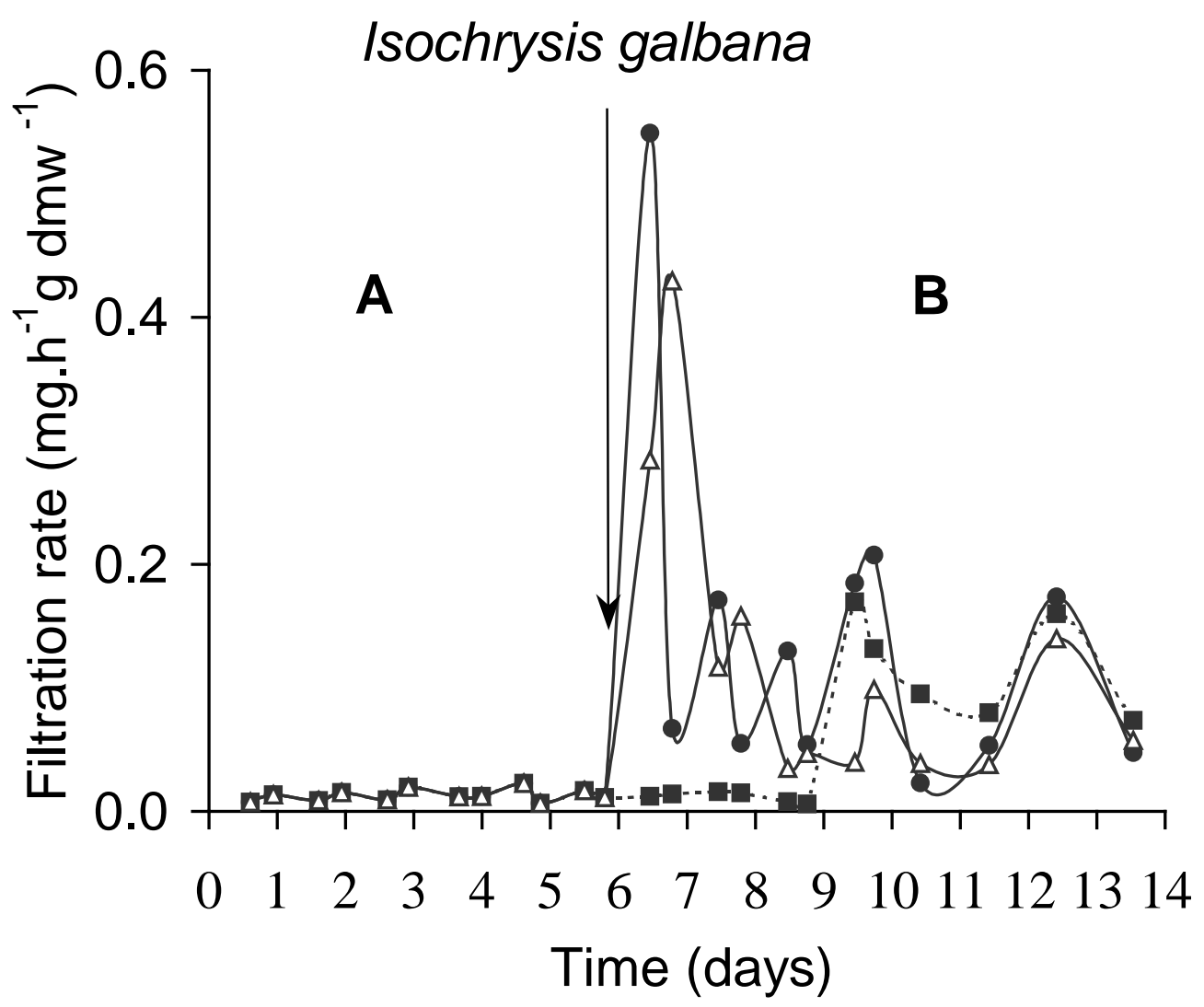


Fig. 3
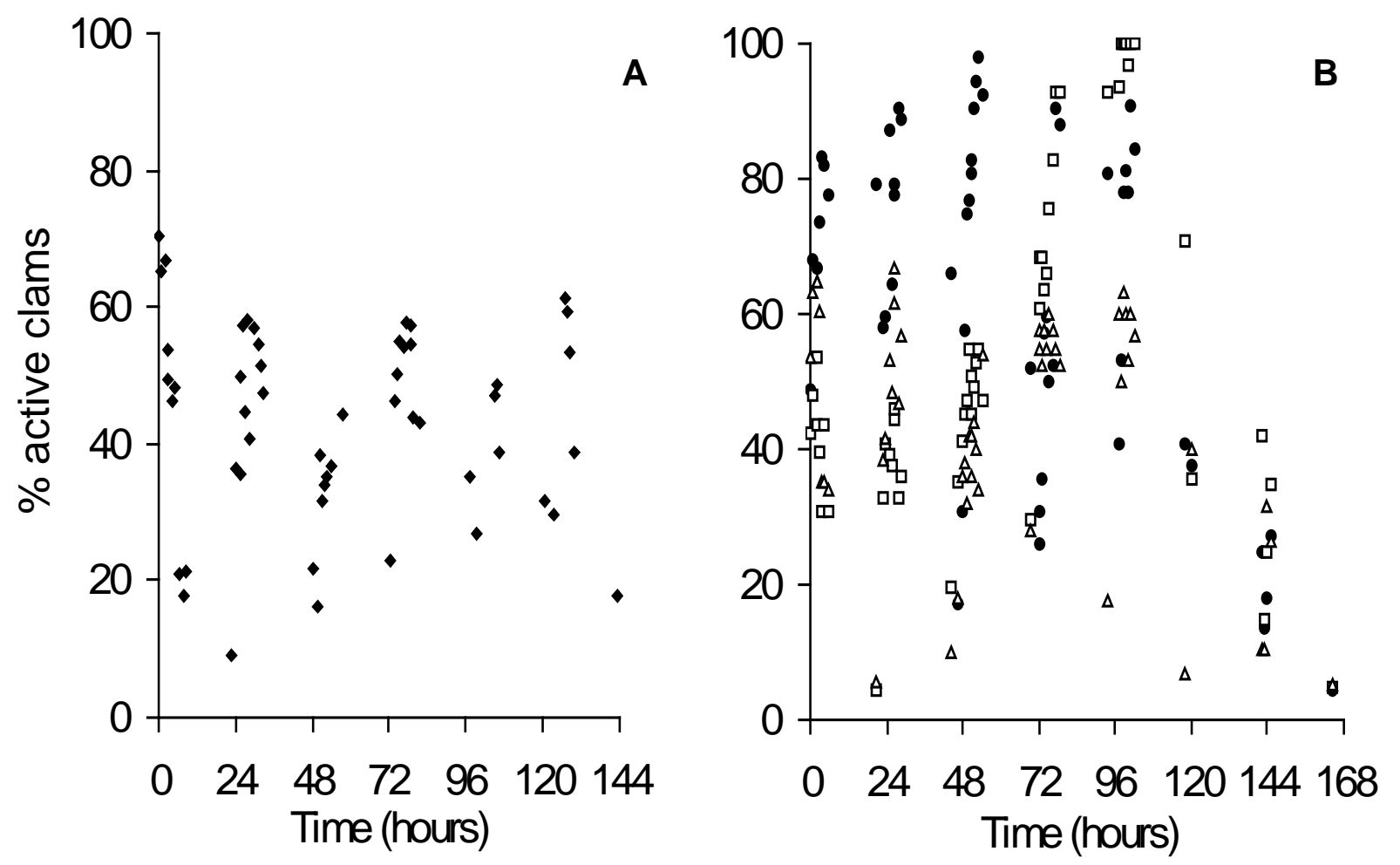
Fig. 4

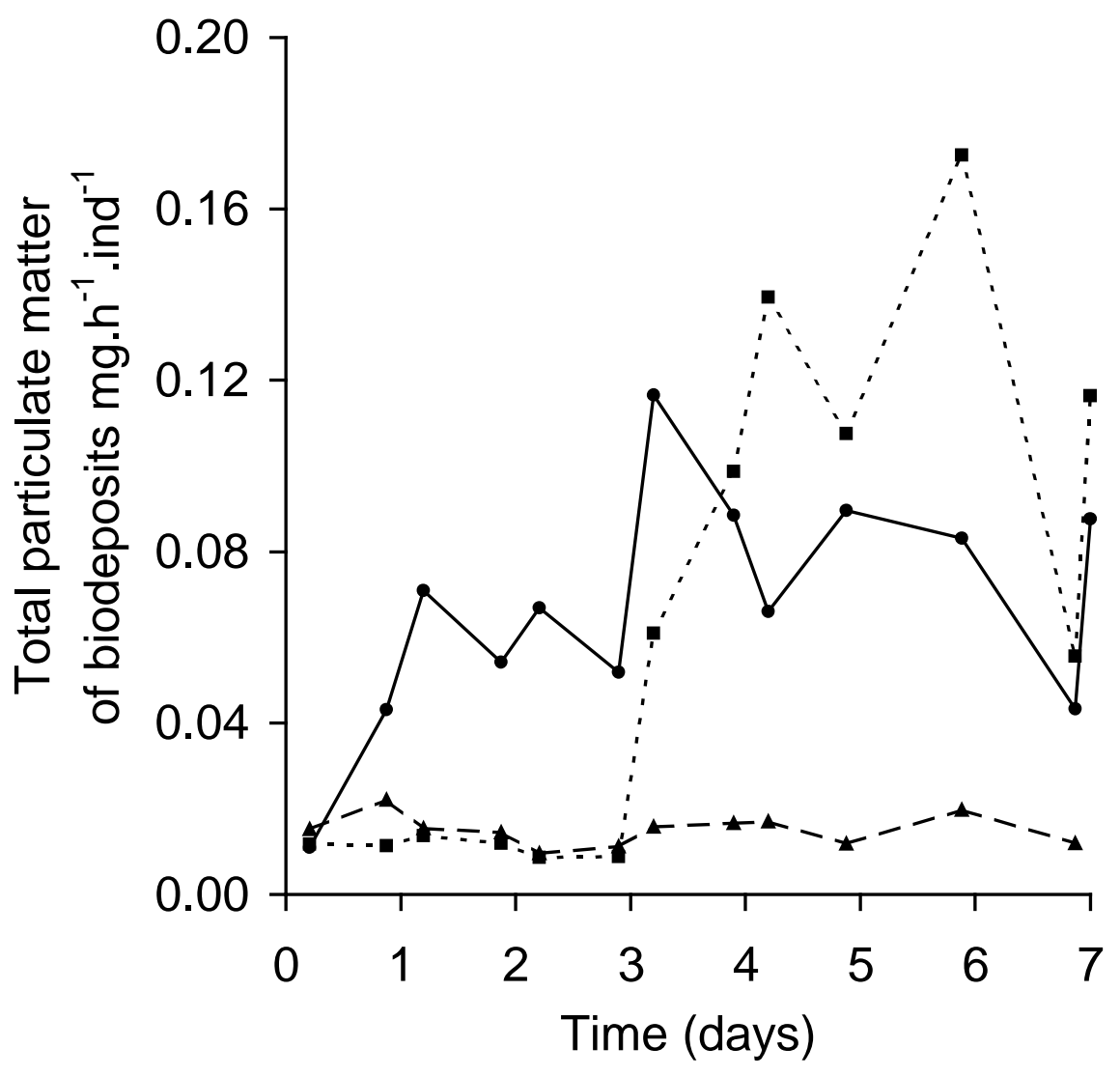


Fig.5

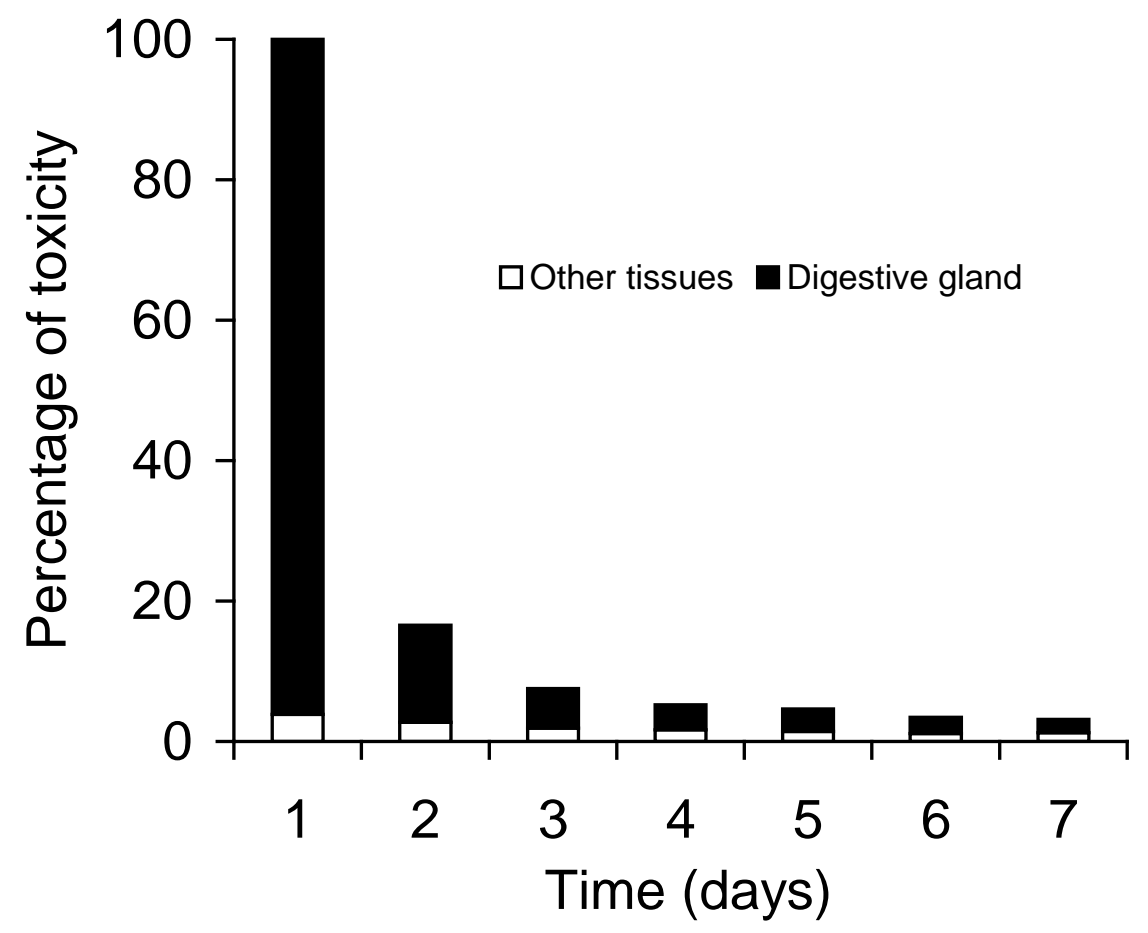


Fig. 6

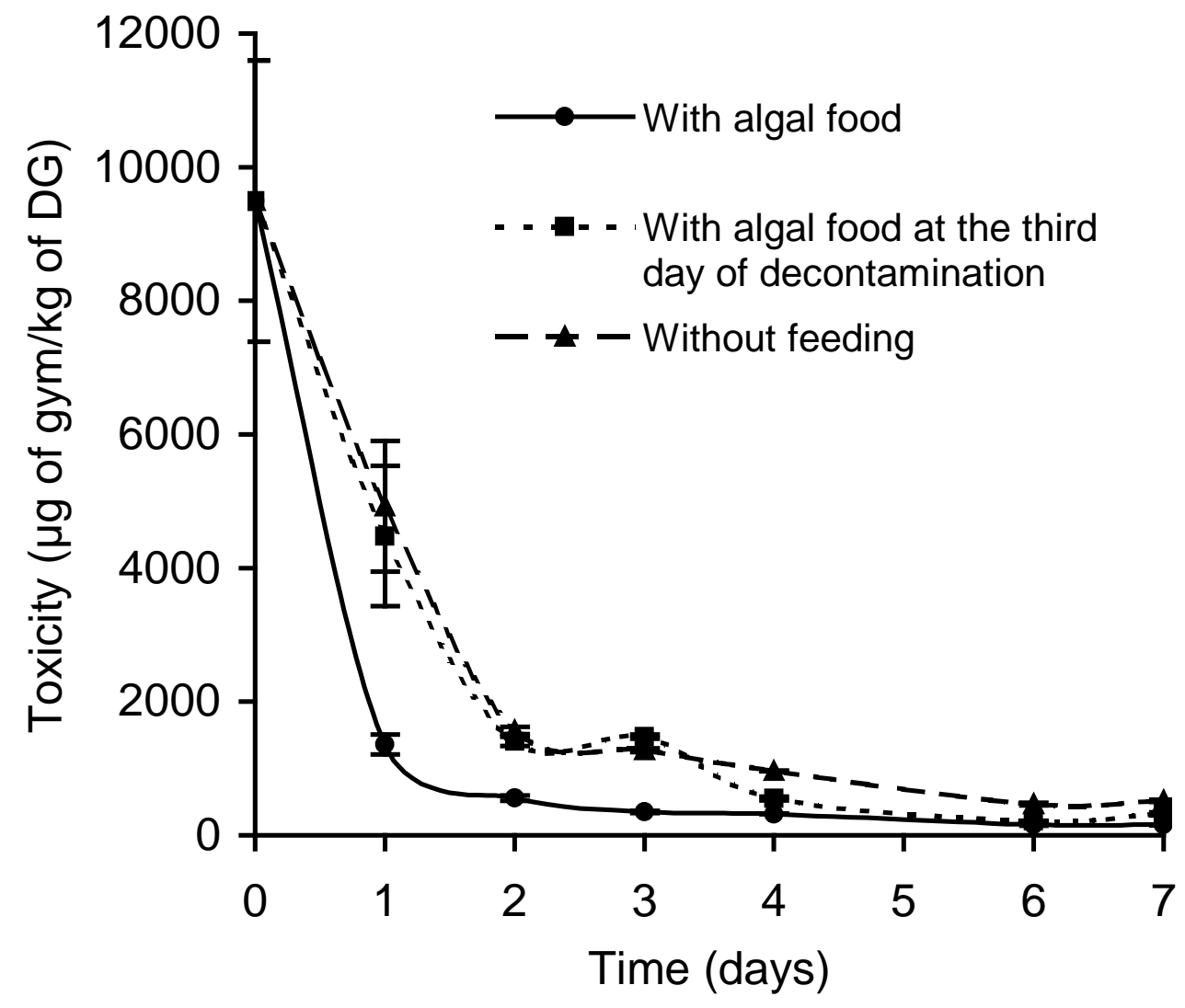


Fig. 7

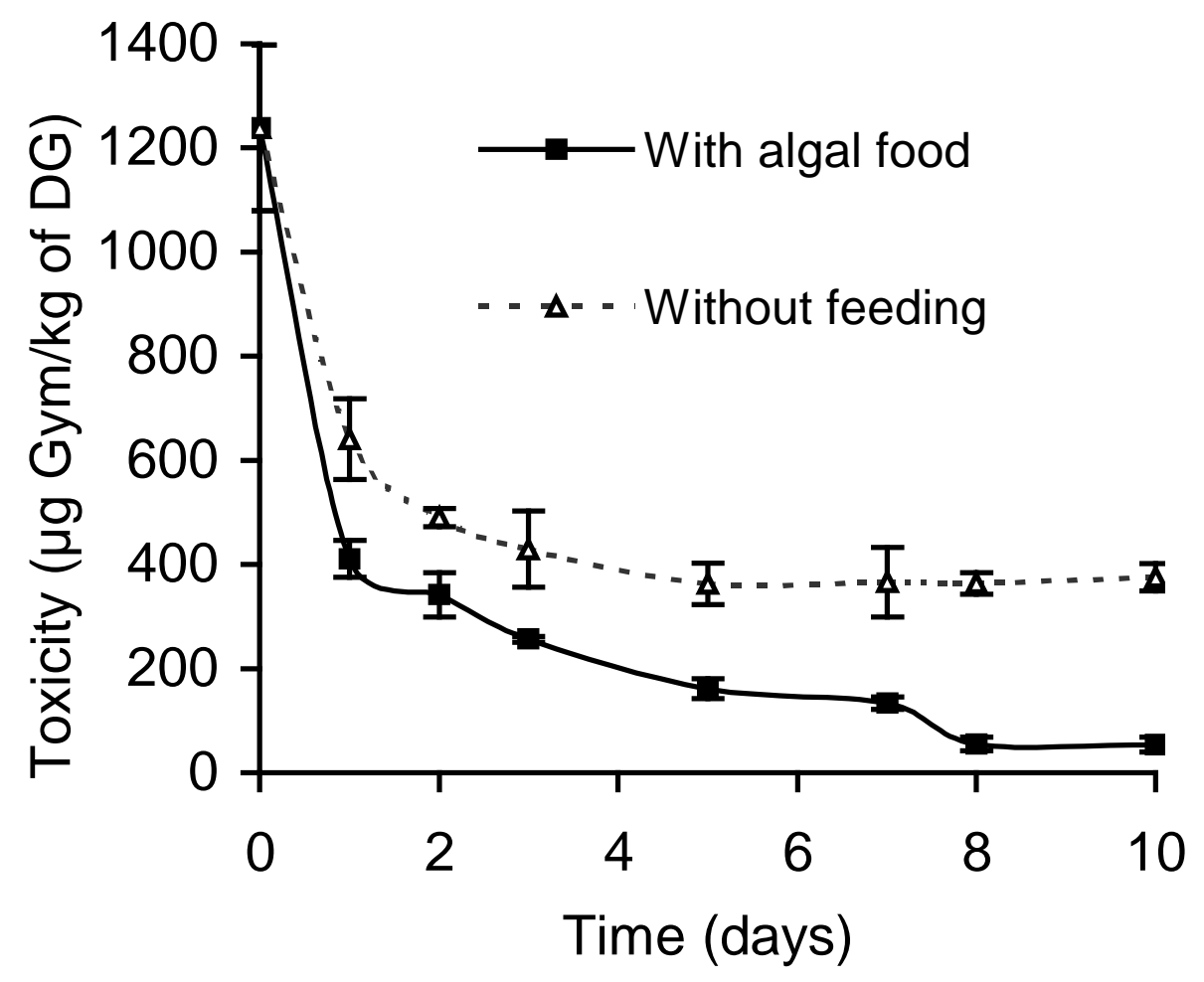

